\title{
ПІДСИСТЕМА ВПРАВ ДЛЯ ФОРМУВАННЯ ПРОФЕСІЙНОЇ ФОНЕТИЧНОӤ КОМПЕТЕНТНОСТІ В АНГЛІЙСЬКІЙ МОВІ ПІСЛЯ НІМЕЦЬКОЇ
}

\begin{abstract}
У статті представлено підсистему вправ для формування фонетичної компетентності майбутніх учителів в англійській мові після німецької. Ураховуючи зміст і иляхи реалізації принципів навчання майбутніх учителів англійської мови після німецької, автор висуває вимоги до вправ і вирізняє їхні типи за спеціальними критеріями, обумовленими особливостями навчання майбутніх учителів вимови другої іноземної мови. Відповідно до етапів формування професійної фонетичної компетентності в англійській мові після німецької виокремлено групи та підгрупи вправ. Для кожної підгрупи запропоновано види вправ, які проілюстровано прикладами.
\end{abstract}

Ключові слова: підсистема вправ, фонетична компетентність, майбутні вчителі, друга іноземна мова.

Постановка проблеми. 3 метою здійснення ефективної професійної діяльності вчитель іноземної мови повинен володіти нормативною іншомовною вимовою, оскільки саме його мовлення в процесі навчання виступає основним орієнтиром для учнів. Тому на момент закінчення ВНЗ майбутні вчителі мають оволодіти фонетичною компетентністю (ФК) на рівні, достатньому для навчання вимови інших. Формування та вдосконалення ФК майбутніх учителів відбувається завдяки організації їхньої навчальної діяльності як вправляння в іншомовному мовленні. Отже, основою ефективного навчання іншомовної вимови є раціонально створена підсистема вправ, що визначає й упорядковує дії викладача та студентів і $\epsilon$ компонентом загальної системи вправ для формування іншомовної комунікативної компетентності.

Аналіз основних досліджень і публікацій. Розробкою вправ для навчання майбутніх учителів іншомовної вимови займалися А. В. Долина [1], О. В. Ланова [2], В. В. Перлова [3] та ін. А. В. Долина запропонувала вправи для удосконалення ФК майбутніх учителів на старшому етапі навчання. О. В. Ланова представила вправи, метою яких $є$ підготовка майбутніх учителів до навчання учнів просодичних засобів. В.В. Перлова розробила вправи для формування слухо-вимовних навичок майбутніх учителів. Зазначимо, що ці розвідки засновані на особливостях процесу навчання вимови англійської мови як першої іноземної (IM1). Проте в умовах сучасної мовної освіти студенти мають можливість вивчати англійську як другу іноземну (IM2), у той час як німецька, як одна 3 найпоширеніших європейських мов досить часто виступає в ролі IM1. Це зумовлює необхідність розробки підсистеми вправ для формування професійної фонетичної компетентності (ПФК) в англійській мові після німецької, що й постає метою нашого дослідження. Для досягнення поставленої мети ми вважаємо необхідним сформулювати вимоги до підсистеми вправ для формування ФК майбутніх учителів в англійській мові після німецької, узагальнити критерії розрізнення типів вправ, а також виділити й описати групи вправ, що складатимуть зазначену підсистему.

Виклад основного матеріалу. Зважаючи на те, що навчальні дії викладача та студентів обумовлені існуючими в природі закономірностями, що відображаються в принципах навчання, вимоги до підсистеми вправ для формування ПФК в ІМ2 ми висуваємо на основі змістового наповнення та шляхів реалізації виділених нами принципів навчання майбутніх учителів англійської мови після німецької [4]. Відтак, на нашу думку, зазначена підсистема повинна включати вправи, що: відповідають рівню мовної та мовленнєвої підготовки майбутніх учителів; сприяють активізації розумової та мовленнєвої діяльності студентів; залучають здобутий майбутніми вчителями досвід оволодіння рідною мовою (PM) та IM1; уможливлюють паралельне тренування фонетичних явищ різних рівнів; забезпечують поетапне формування фонетичних навичок і вмінь; сприяють професійній орієнтації процесу навчання вимови IM2; розвивають здатність студентів до рефлексії та самоаналізу; сприяють систематизації знань майбутніх учителів щодо особливостей фонетичного оформлення англомовного мовлення порівняно 3 PM та IM1; надають можливість одночасного формування фонетичних та інших мовленнєвих навичок i вмінь; створюють умови для регулярного використання виучуваного фонетичного матеріалу в різних контекстах з його поступовим поглибленням і розширенням; формують і підтримують позитивне ставлення до процесу оволодіння вимовою IM2.

Аналіз науково-методичної літератури [5; 6] дозволяє виділити основні типи вправ, що можуть бути використані в процесі навчання вимови, за загальними критеріями: спрямованість на прийом або видачу інформації (рецептивні, рецептивно-репродуктивні, рецептивно-продуктивні, продуктивні); комунікативність (некомунікативні, умовно-комунікативні); вмотивованість (вмотивовані, невмотивовані); рівень керування діями студентів (з повним керуванням, 3 частковим керуванням, 3 
мінімальним керуванням); наявність / відсутність опор (без опор, зі спеціально створеними опорами); наявність / відсутність ігрового компонента (без ігрового компонента, 3 нерольовим ігровим компонентом, з рольовим ігровим компонентом); спосіб виконання вправи (фронтальні, хорові, групові, парні, індивідуальні). Але, зважаючи на визначені нами вимоги й особливості формування ПФК в IM2, ми також розрізнюємо додаткові типи вправ за спеціальними критеріями, до яких ми відносимо: кількість цілей (багатоцільові та моноцільові вправи); професійна спрямованість (професійно спрямовані, без професійної орієнтації); рефлексивність (рефлексивні, не рефлексивні); характер мовленнєвого матеріалу (мультилінгвальні, білінгвальні, монолінгвальні).

Доцільність використання виділених типів вправ за загальними критеріями під час навчання майбутніх учителів іншомовної вимови вже була доведена науковцями [1; 3], тому не потребує додаткового обгрунтування. Перейдемо до розгляду особливостей використання додаткових типів вправ, що вирізняються нами за спеціальними критеріями.

Більшість розроблених нами вправ є багатоиільовими, що виявляється, по-перше, в одночасному тренуванні артикуляційних, акцентологічних та інтонаційних навичок i, по-друге, у формуванні поряд із фонетичними навичками інших мовленнєвих навичок і вмінь. 3 цією метою ми пропонуємо під час введення фонетичного матеріалу звертати увагу студентів не тільки на особливості вимови звуків, але й на інтонаційне оформлення мовленнєвого зразка. Крім того, при виконанні вправ на імітацію або читання вголос слів / словоформ із виучуваним звуком студенти можуть отримати додаткове завдання, спрямоване на тренування мелодичних типів (наприклад, повторення слів із варіюванням низхідної та висхідної мелодики). Такі вправи, на нашу думку, готують майбутніх учителів до складніших завдань у репродукуванні інтонаційного оформлення фраз і більших відрізків мовлення. Одночасне тренування фонетичних і лексичних навичок може відбуватися під час заповнення студентами пропущених у тексті лексичних одиниць із виучуваним звуком в аудіюванні, а формування навичок використання низхідної мелодики - супроводжуватися тренуванням граматичних навичок постановки спеціальних запитань i розвитком умінь діалогічного мовлення.

За критерієм професійної спрямованості ми вирізняємо професійно спрямовані вправи, метою яких $є$ розвиток у майбутніх учителів здатності до навчання вимови інших. Їхнє виконання відбувається здебільшого після автоматизації дій студентів із виучуваним фонетичним матеріалом на текстовому рівні. На цьому етапі рівень сформованості слухо-вимовних навичок і набутих знань можна вважати достатнім для, наприклад, ідентифікації вимовних помилок у чужому мовленні та їхньої корекції. При цьому, сприйняття мовлення, насиченого помилками, не призводить до формування у свідомості студентів некоректного образу-еталону, а отже, не позначається на процесі оволодіння іншомовною вимовою. До професійно орієнтованих ми також відносимо вправи в набутті студентами фонетичних знань і розвитку в них диференційної чутливості до елементів фонетичної системи IM2 у порівнянні 3 PM та IM1. Оскільки такі вправи створюють орієнтири для правильного відтворення фонетичного явища, їхнє виконання передує тренуванню англомовної вимови на рівні слів і більших мовленнєвих одиниць.

Слідом за А.В. Долиною [1] для забезпечення умов навчальної автономії нами передбачені рефлексивні вправи, що полягають в самоспостереженні за процесом оволодіння ФК в ІМ2. Так, ми пропонуємо майбутнім учителям під час виконання самостійної роботи створювати аудіозаписи власного англомовного мовлення. Аналізуючи їх, студенти виявляють вимовні помилки, визначають їхні причини та способи подолання.

За характером мовленнєвого матеріалу, що використовується у вправах, ми розрізнюємо монолінгвальні, білінгвальні та мультилінгвальні вправи. Монолінгвальні вправи грунтуються виключно на англомовному мовленнєвому матеріалі. До білінгвальних ми відносимо вправи, що, поряд 3 англомовними мовленнєвими одиницями, містять мовленнєвий матеріал лише однієї з контактуючих мов (німецької або РМ). Мультилінгвальними ми називаємо вправи, у яких англомовні мовленнєві одиниці співставляються з відповідними одиницями як німецької, так і РМ.

Проаналізувавши спеціальні критерії та визначені за ними типи вправ, перейдемо до розгляду підсистеми вправ для формування ФК майбутніх учителів в англійській мові після німецької (див. рис. 1). Відповідно до етапів формування ПФК в IM2 [4] вона складається 3 чотирьох груп: 1) для ознайомлення студентів із новим фонетичним матеріалом (I); 2) для автоматизації дій із фонетичним матеріалом на рівні слова / словоформи, словосполучення, фрази, понадфразової та діалогічної єдностей (II); 3) для автоматизації дій із фонетичним матеріалом на рівні міні тексту / тексту (III); 4) для формування професійних умінь майбутніх учителів, що вирізняються нами у складі ПФК в IM2 (IV) [7]. 


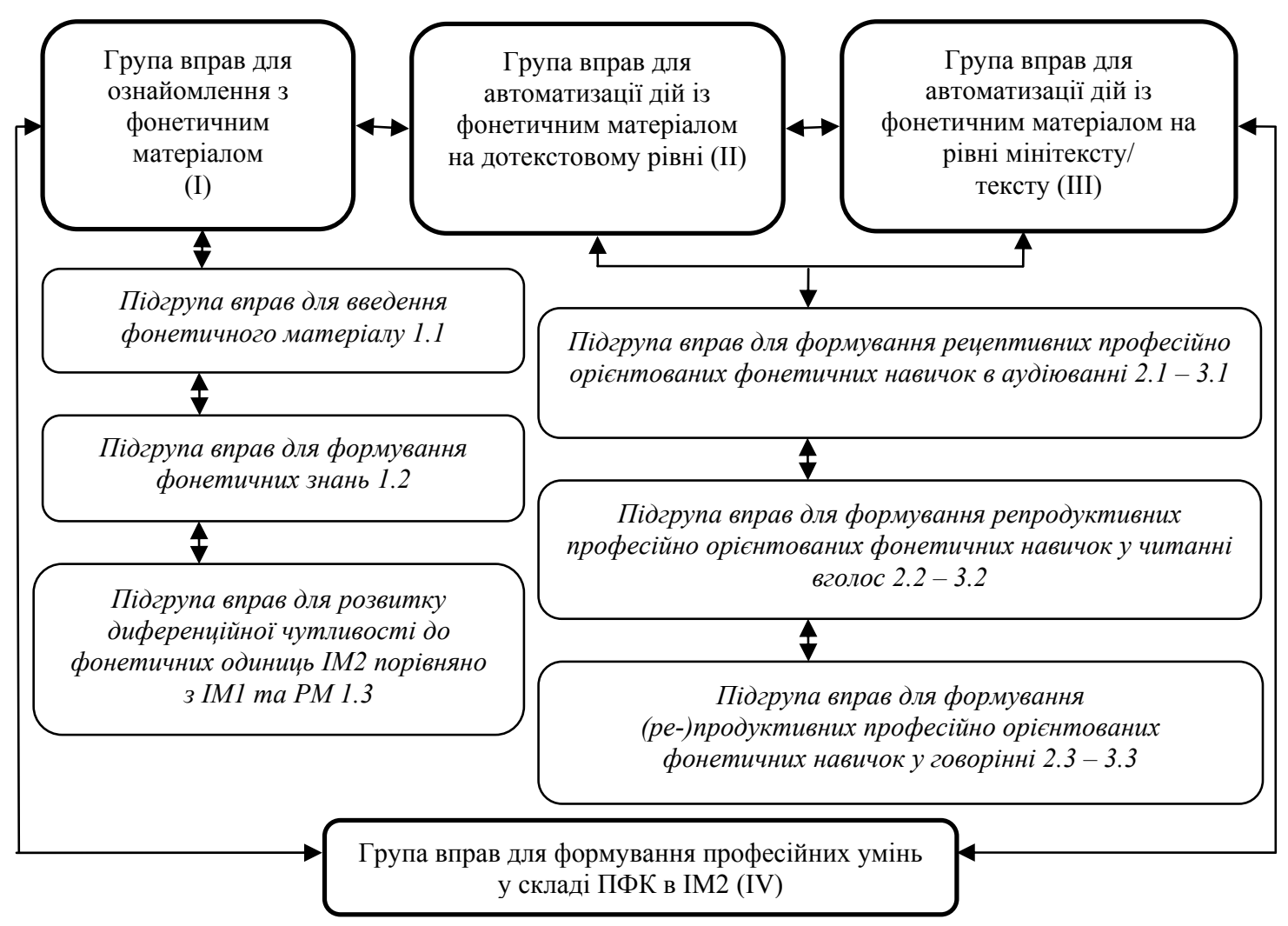

Рис. 1. Підсистема вправ для формування ПФК в IM2

Розглянемо та проілюструємо прикладами кожну групу вправ окремо.

Метою групи I є презентація нових фонетичних одиниць у контексті з їх подальшим аналізом i набуттям студентами знань щодо особливостей фонетичного оформлення англомовного мовлення в порівнянні з IM1 та РМ. Мета обумовлює поділ групи на три підгрупи: 1) для введення фонетичного матеріалу в контексті $(1.1)$; 2) для набуття студентами фонетичних знань (1.2); 3$)$ для розвитку диференційної чутливості до фонетичних елементів англійської мови порівняно з IM1 та РМ (1.3).

Дотримуючись принципу інтегративного навчання видів мовленнєвої діяльності й аспектів мови, при розробці вправ підгрупи 1.1 ми використовуємо діалоги та монологи, що є насиченим виучуваним фонетичним явищем і що ілюструють функціонування лексичного та граматичного матеріалу, який має бути засвоєний на початковому етапі вивчення IM2 у ВНЗ. Це, здебільшого, рецептивні вправи, серед яких ми вирізнясмо: аудіювання діалогів і монологів; визначення кількості складів у словах із представленого відрізка мовлення; локалізація наголосу в словах із прослуханого діалогу / монологу; локалізація фразового наголосу; локалізація пауз; визначення типів мелодики у фразах із прослуханого діалогу / монологу; впізнавання спільного звука для групи слів із запропонованого відрізка мовлення; ідентифікація звуків у словах із діалогу / монологу.

3 огляду на те, що викладачеві важко проконтролювати правильність виконання таких вправ, ми пропонуємо здійснювати контроль за допомогою зовнішніх дій (напр., відстукування пауз, плескання в долоні з метою локалізації фразового наголосу, позначення жестами низхідної та висхідної мелодики тощо). Їхнє використання забезпечує задіяння різних видів аналізаторів і відповідає необхідності дотримання принципу міцності навчання. Крім того, майбутні вчителі оволодівають професійно цінним умінням унаочнювати процес навчання, що необхідно при поясненні учням нового матеріалу, виправленні помилок та ілюстрації функціонування фонетичних явищ у мовленні.

Слід також зазначити, що в більшості з цих вправ майбутнім учителям пропонується відповісти на питання аналітичного характеру, які грунтуються на порівнянні особливостей інтонаційного оформлення англомовного мовлення 3 IM1 і РМ. При цьому студенти надають власні приклади, які ілюструють функціонування фонетичних явищ, що опрацьовуються, у відповідних відрізках мовлення інших мов. У таких спосіб майбутні вчителі оволодівають здатністю до самостійного пошуку спільних і відмінних рис фонетичної системи англійської, німецької та РМ, що сприяє розвитку їхньої фонетичної усвідомленості.

Наведемо приклади розроблених нами вправ підгрупи 1.1.

Приклад 1

Мета: ознайомлення студентів зі звуками $[\mathrm{k}, \mathrm{g}, \wedge, \mathrm{a:}]$ та мелодикою альтернативних питань. 
Тип вправи: рецептивна, умовно-комунікативна, мультилінгвальна (Step 1).

Вид вправи: аудіювання діалогу з використанням текстової опори; визначення типів мелодики.

Завдання: Step 1. Listen to the dialogue. What melody do you hear in the underlined phrases?

Carla: Chuck, would you like to go camping or rock climbing this weekend?

Chuck: Well, Carla, I'm not very keen on climbing. Let's go camping instead. It'll be great fun.

Carla: OK. I love camping. Do you want to take Greg or Margaret with us?

Step 2. Listen to the underlined sentences again and show the change of melody with your hand.

Step 3. What melody is used in such sentences in German? What about Ukrainian and Russian? Give examples.

Приклад 2

Мета: ознайомлення студентів зі звуками [k, g, ^, a:].

Тип вправи: рецептивна, некомунікативна, монолінгвальна.

Вид вправи: впізнавання спільного звука для групи слів із діалогу.

Завдання: Step 1. Listen to the words from the dialogue (див. приклад 1) and define the common sound for each group:

$[\ldots][\ldots][\ldots][\ldots]$

\begin{tabular}{|l|l|l|l|l|l|l}
\hline $\begin{array}{r}\text { keen } \\
\text { take }\end{array}$ cooking & $\begin{array}{l}\text { go Margaret } \\
\text { guitar good }\end{array}$ & $\begin{array}{l}\text { can't ask } \\
\text { darts cards }\end{array}$ & $\begin{array}{l}\text { love fun } \\
\text { Chuck but }\end{array}$ \\
\hline
\end{tabular}

Step 2. Give two more examples of words from the dialogue that have these sounds.

При введенні звукових одиниць, що є ідентичними до відповідних елементів фонетичної системи німецької мови, ми пропонуємо використовувати останню в якості опори. Це, на нашу думку, полегшить процес формування ФК, оскільки студенти сприйматимуть фонетичний матеріал як уже засвоєний під час вивчення IM1 (див. приклад 3).

Приклад 3

Мета: ознайомлення студентів зі звуками $\left.\left[\int, 3, t\right], d z\right]$.

Тип вправи: рецептивна, некомунікативна, білінгвальна.

Вид вправи: ідентифікація звуків у словах.

Завдання: Step 1. Listen to the words from the dialogue and put them under the German word that has a similar consonant sound:

1. show

2. teenager

3. much

4. beige

5. $\quad \ldots$

\begin{tabular}{|c|c|c|c|}
\hline schade [S] & Genie [3] & Deutsch $[\mathrm{t}]$ & Job [ds] \\
\hline & $\ldots$ & $\ldots$ & $\ldots$ \\
\hline
\end{tabular}

Step 2. Give one more example of a word from the dialogue for each sound.

Введення фонетичного матеріалу супроводжується самостійним виведенням студентами умовисновків щодо особливостей фонетичного оформлення англомовного мовлення порівняно 3 німецькою та РМ, що є метою підгрупи 1.2. До неї ми відносимо вправи на заповнення тексту правила 3 пропусками, визначення фонологічних характеристик звукових одиниць, заповнення порівняльних таблиць і відповіді на запитання на основі аналітичної діяльності (див. приклад 4).

Приклад 4

Мета: формування фонетичних знань.

Тип вправи: репродуктивна, некомунікативна (Step 1); продуктивна, комунікативна, мультилінгвальна (Step 2).

Вид вправи: визначення фонологічних характеристик звуків (Step 1); відповіді на запитання на основі аналітичної діяльності (Step 2).

Завдання: Step 1. Look at the profile of the articulation of the English sound [h]. Pronounce this sound and underline its phonological characteristics:

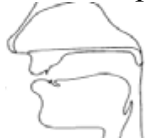

[h] - noise / sonorant, forelingual / mediolingual / backlingual / glottal, occlusive/constrictive/occlusiveconstrictive.

Eng. [h] 
Step 2. Analyze the profiles of the articulation of the German and Ukr/Rus. sounds. Pronounce the German [h] like in 'Haus', [x] like in 'Buch', [s] like in 'ich' and the Ukr/Rus. [x] like in 'холодно'. Define which sound is identical to the English [h]? Which sounds are different from it? In what way?
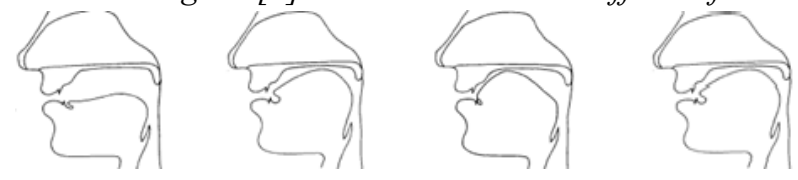

Germ. [h] Germ. [x] Germ. [ç] Ukr/Rus. [x]

Розвиток диференційної чутливості до фонетичних одиниць англійської мови в порівнянні з IM1 та РМ сприяє утворенню у свідомості майбутніх учителів вимовного еталону, що є основою формування в них професійно-орієнтованих фонетичних навичок в IM2. Більш того, здатність розрізнювати елементи фонетичних систем виучуваних мов $є$ передумовою оволодіння студентами професійними вміннями ідентифіковувати та локалізовувати вимовні помилки в чужому англомовному мовленні. Серед розроблених нами вправ для розвитку диференційної чутливості до фонетичних елементів англійської мови порівняно з IM1 та РМ (підгрупа 1.3) ми розрізнюємо рецептивні та рецептивно-репродуктивні вправи на: ідентифікацію англійського звука в парі звуків англійської та IM1, англійської та PM; ідентифікацію англійського звука в групі звуків англійської, німецької та РМ; ідентифікацію англійського слова в білінгвальних парах; ідентифікацію англійського слова в групі слів англійської, німецької та РМ; диференціацію звуків у білінгвальних парах; диференціацію звуків у групі слів англійської, німецької та РМ; імітацію виучуваного звука англійської мови на контрасті зі звуком IM1 або РМ, що є об'єктом мовного перенесення; імітацію білінгвальних пар із використанням графічної опори; імітацію англійських слів, словосполучень і речень, що містять виучуване фонетичне явище, на контрасті з відповідними мовленнєвими одиницями IM1 та РМ з використанням графічної опори (див. приклад 5).

Приклад 5

Мета: формування вмінь диференціації англ. [э] у порівнянні з нім. [р] та укр. / рос. [н].

Тип вправи: рецептивна, некомунікативна, мультилінгвальна.

Вид вправи: диференціація звуків у білінгвальних парах.

Завдання: Listen to the pairs of words. Put + if their final sounds are the same or - if they are different:

\begin{tabular}{|c|ll|r|}
\hline \multicolumn{2}{|c|}{ Languages } & \multicolumn{3}{|c|}{ Pairs of words } & $+/-$ \\
\hline Eng. & 1. & bunk - Bank & \\
Germ. & 2. & lung - lang & \\
\hline Eng. & 3. & lung - лан & \\
Ukr. & 4. & sung - сан & \\
\hline Eng. - & 5. & sing - сын & \\
Rus. & 6. & bang - Бен & \\
\hline
\end{tabular}

Метою Груп II і III $\epsilon$ формування в майбутніх учителів фонетичних навичок в аудіюванні, читанні вголос і говорінні на дотекстовому та текстовому рівнях відповідно. За видом мовленнєвої діяльності кожна група поділяється на три підгрупи. Підгрупи 2.1 і 3.1 націлені на формування професійно орієнтованих фонетичних навичок аудіювання та включають монолінгвальні рецептивні вправи на: диференціацію та ідентифікацію звуків, їх модифікацій, моделей ритму та типів мелодики в словах, словосполученнях і фразах; ідентифікацію звуків, модифікацій звуків, інтонаційних засобів у діалогічному та монологічному мовленні; визначення на слух словесного наголосу, фразового наголосу, пауз, мелодичних типів у графічній опорі або за допомогою зовнішніх дій; схематичне відтворення моделей ритму після сприйняття фраз на слух; фонематичні диктанти; групування слів за фонетичними ознаками; графічне відтворення інтонаційних засобів у діалогічному та монологічному мовленні в текстовій опорі.

Слід зауважити, що переважна більшість розроблених нами вправ на диференціацію та ідентифікацію $\epsilon$ ускладненими, оскільки вимагають концентрації уваги студентів одночасно на кількох фонетичних аспектах (наприклад, звуках і типах мелодики, звуках і ритмічних моделях). Оскільки професійна діяльність учителя передбачає постійне розподілення уваги, виконання таких вправ розвиває в майбутніх учителів необхідні професійні якості (див. приклад 6).

\section{Приклад 6}

Мета: формування фонетичних навичок сприйняття на слух звуків $[\theta$, б] і низької низхідної та висхідної мелодики.

Тип вправи: рецептивна, некомунікативна, монолінгвальна.

Вид вправи: ідентифікація звуків і типів мелодики.

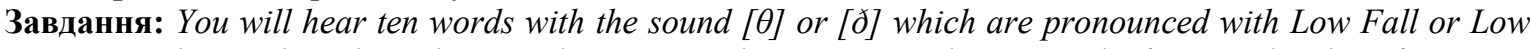
Rise. Listen to the words and put their numbers next to the correct combination. The first word is done for you: 


\begin{tabular}{|c|c|}
\hline $\begin{array}{ll}{[\theta]} & + \\
& \end{array}$ & \\
\hline$[\theta]+\widetilde{~}$ & 1 \\
\hline$[ð]+\infty$ & \\
\hline$[ð]+\widetilde{\sigma}$ & \\
\hline
\end{tabular}

Виконання вправ підгруп 2.1 і 3.1 може супроводжуватися формуванням суміжних лексичних $\mathrm{i}$ граматичних навичок, а також мовленнєвих умінь, що забезпечує багатофункціональність вправ, а отже, інтенсифікує процес вивчення IM2 (див. приклад 7).

Приклад 7

Мета: формування навичок ідентифікації звуків [s, z] в аудіюванні.

Тип вправи: рецептивна, комунікативна, монолінгвальна.

Вид вправи: ідентифікація звуків у монологічному мовленні; аудіювання монологу.

Завдання: Step 1. Listen and put up 1 finger if you hear [s] or 2 fingers if you hear [z] in the words in bold.

Hi, I'm Tom Taylor and I'm from Leeds, England. This is my Dad, Frank, and his favourite car. Cars are his hobby. Now meet my mum, Rebecca, and my sister Emily. My mum is a teacher. She's got many students. Emily's hobby is reading books. ...

Step 2. Are the following statements True or False?

1. Tom is from Great Britain. 2. Tom's father likes driving. 3. Emily doesn't like reading books. 4. ...

Доволі багато студентів тільки починають вивчати англійську мову у ВНЗ, що обумовлює необхідність формування в них навичок встановлення та реалізації графемно-фонемних відповідностей, наголошення слів та інтонаційного оформлення мовлення під час читання. Інші, хоча й мають досвід вивчення англійської мови, часто припускаються помилок під час озвучування англійських слів, речень $\mathrm{i}$ текстів. Тому, визначаючи типи та види вправ для формування професійно орієнтованих фонетичних навичок у читанні вголос, ми звертаємося насамперед до технічного боку читання. Відтак, підгрупи 2.2 i 3.2 складаються з рецептивно-репродуктивних і репродуктивних монолінгвальних і білінгвальних вправ, серед яких ми розрізнюємо: імітацію слів, мінімальних пар, речень і текстів із використанням графічної опори; імітацію слів, що містить виучуваний звук, з варіюванням мелодики; читання вголос слів, мінімальних пар і речень; читання вголос слів із варіюванням мелодики; римування слів та їх читання уголос; читання вголос речень із варіюванням фразового наголосу; читання вголос речень із демонстрацією за допомогою невербальних дій фразового наголосу, пауз і типів мелодики; читання вголос коротких текстів за певний відрізок часу; читання вголос коротких текстів із позначенням пауз 'відстукуванням' або плесканням у долоні; читання вголос коротких текстів із демонстрацією за допомогою жестів фразового наголосу та типів мелодики; читання римівок, скоромовок, віршів.

Вправи на імітацію слів, як правило, супроводжуються завданням на виведення студентами правила щодо відповідності звука англійської мови певній графемі або сполученню графем, що створюють у них системне уявлення про особливості читання слів у IM2. При цьому увага студентів також звертається на слова, графемно-фонемні відповідності в яких є менш поширеними в англійські мові.

Позитивному перенесенню з інших мов сприятимуть, на нашу думку, розроблені нами завдання до вправ підгруп 2.2 і 3.2. Під час опрацювання звуків, що є ідентичними до фонетичних одиниць IM1 або PM, в інструкції до вправи ми рекомендуємо вимовляти зазначений звук, як у цій мові. Якщо англійський звук відрізняється від звуків інших мов, студенти отримують завдання модифікувати вже знайомий їм звук іншої мови, що є найближчим до нього за фонетичними характеристиками (напр. 'Read the words. To pronounce the sound [ว:] correctly, say the German [o:] like in 'Sohn' and open your mouth a little wider') (див. приклад 8).

\section{Приклад 8}

Мета: формування навичок вимови звуків $[\mathrm{k}, \mathrm{g}]$ у читанні вголос; формування навичок використання низької висхідної та низхідної мелодики альтернативних запитань.

Тип вправи: рецептивно-репродуктивна, некомунікативна, білінгвальна (Step 1).

Вид вправи: імітація слів 3 використанням графічної опори (Step 1); читання вголос слів 3 варіюванням мелодики (Step 3); читання вголос речень 3 демонстрацією типів мелодики за допомогою жестів (Step 4).

Завдання: Step 1. Listen and repeat. Pronounce the sounds [k, g] like in German:

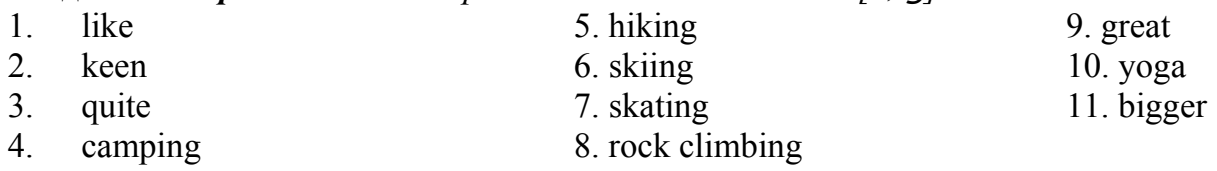


Step 2. Look at the words from Step 1 and write down the usual spelling for the sounds [k, $g]$ :

\begin{tabular}{|c|l|c|l|}
\hline \multirow{2}{*}{ sounds } & \multicolumn{2}{|c|}{ usual spelling } & \multicolumn{1}{|c|}{ but also! } \\
\cline { 2 - 3 } & \multicolumn{2}{|c|}{ Letters } & \multicolumn{1}{|c|}{ examples } \\
\hline \multirow{4}{*}[\mathrm{k}]{} & 1. & & \\
\cline { 2 - 3 } & 2. & & \\
\cline { 2 - 3 } & 3. & & ghost \\
\cline { 2 - 3 } & 4. & & \\
\hline \multirow{2}{*}[\mathrm{g}]{} & 1. & & \\
\cline { 2 - 3 } & 2. & & \\
\hline
\end{tabular}

Step 3. Read the words from Step 1 varying Low Fall and Low Rise.

Step 4. Read the following sentences aloud using Low Rise + Low Fall. Show the change of melody with your hand.

1. Do you like camping or hiking?

2. Are you keen on skiing or skating?

...

Розробляючи вправи на читання вголос текстів за певний відрізок часу, ми виходили із середнього темпу англомовного мовлення, що складає 240 складів за хвилину. При цьому студентам пропонується спочатку прочитати текст повільно, спираючись на інтонаційну розмітку, а потім у нормальному темпі. Крім того, особливу увагу ми приділяємо формуванню навичок паузації, що є необхідними для здійснення успішної професійної діяльності. Так, при поясненні нового матеріалу, введенні лексики або під час роботи з початківцями вчитель свідомо уповільнює темп, що рекомендовано робити саме шляхом збільшення тривалості пауз між смисловими частинами висловлювання [5] (див. приклад 9).

Приклад 9

Мета: формування навичок паузації в читанні вголос.

Тип вправи: репродуктивна, умовно-комунікативна, монолінгвальна.

Вид вправи: читання вголос тексту за певний відрізок часу.

Завдання: Step 1. Read the text. Fill in the gaps with the correct forms of adjectives and put $\mid$ for a short pause and $\|$ for a long pause:

This is a photo of me and my friend, Sophie. She's nineteen, so she's a little 1) (old) than me. She lives in England and now she's at university. She's 2) (tall) than me and 3) (slim). She has got dark hair but it's a bit 4) ___ (short) than my hair. ...

Step 2. Listen and check. Read the text aloud, clap your hands once for a short pause and twice for a long pause.

Step 3. Read the text again in a normal tempo. You have 35 seconds to do it.

Використовуючи фонетичний, лексичний і граматичний матеріал, що має бути засвоєний на початковому етапі вивчення IM2, ми уклали вправи на формування в майбутніх учителів ФК у говорінні. Вправи підгрупи 2.3 мають на меті формування професійно орієнтованих фонетичних навичок говоріння на дотекстовому рівні. Це вправи на реплікування (підстановку, трансформацію, відповіді на запитання, повідомлення або запит інформації, спонукання до дій тощо), самостійне вживання різних видів діалогічних єдностей та об'єднання зразків мовлення в понадфразову єдність. Вправи підгрупи 3.3 спрямовані на формування в майбутніх учителів ФК у говорінні на рівні тексту. Серед них ми розрізнюємо створення діалогів на основі заданої комунікативної ситуації, а також власного висловлювання текстового рівня з використанням опори. За своїм характером вправи зазначених підгруп $\epsilon$ рецептивно-репродуктивними або рецептивно-продуктивними. За аналогією з вправами на імітацію та читання вголос, більшість із них містить інструкцію з рекомендацією відштовхуватися від уже знайомої мови з метою досягнення правильної вимови фонетичних одиниць, що опрацьовуються (див. приклад $10)$.

\section{Приклад 10}

Мета: формування вмінь діалогічного мовлення; формування навичок вимови звука [3:] i використання високої висхідної мелодики здивування.

Тип вправи: рецептивно-репродуктивна, умовно-комунікативна, білінгвальна.

Вид вправи: підстановка у зразок мовлення.

Завдання: Work in pairs. Tell your partner some gossips about your groupmates' friends/relatives choosing from the table below. To pronounce the sound [3:] correctly in the words in bold say the German [Ø:] like in 'böse' but move the tongue a little back and put the lips in neutral position: 


\begin{tabular}{|c|c|c|c|}
\hline I heard & $\begin{array}{l}\ldots \text { ' granny lived in } \\
\ldots \text { ' sister worked as a } \\
\ldots \text { ' ancestors were from } \\
\ldots \text { ' parents went on a journey to } \\
\ldots \text { ' brother wanted to become a }\end{array}$ & $\begin{array}{l}\text { Turkey } \\
\text { Germany } \\
\text { nurse } \\
\text { journalist }\end{array}$ & $\begin{array}{l}\text { Did she? } \\
\text { Were they? } \\
\text { Did they? } \\
\text { Did he? }\end{array}$ \\
\hline
\end{tabular}

Example:

- I heard Ann's granny lived in Turkey.

- Did she? I heard she lived in Germany.

Професійна спрямованість процесу навчання майбутніх учителів забезпечується виконанням вправ Групи IV, що мають на меті формування професійних умінь із навчання іншомовної вимови інших. Спираючись на професійні вміння у складі ПФК в IM2 [7], до цієї групи ми відносимо вправи на: ідентифікацію вимовних помилок у чужому мовленні; ідентифікацію вимовних помилок у своєму мовленні; аналіз вимовних помилок на джерело інтерференції та їхні можливі наслідки для процесу комунікації. Зазначимо, що ідентифікація помилок, як правило, супроводжується виконанням додаткових завдань на їх виправлення та демонстрацію правильної вимови в говорінні або читанні вголос слів, речень і текстів у транскрипції.

Ми також звертаємо увагу на те, що під час розробки цих вправ ми використовували мовленнєвий матеріал трьох типів: 1) продукований німецькомовними мовцями, які мають досвід оволодіння лише однією IM (англійською); 2) продукований мовцями, які є носіями РМ студентів і які вивчають англійську як єдину іноземну; 3) продукований мовцями, які є носіями РМ студентів і для яких англійська є IM2 після німецької. Мовленнєвий матеріал першого типу фокусує увагу студентів на вимовних помилках, що спричинені перенесенням 3 німецької мови, а другого - РМ, що не лише полегшує ідентифікацію помилок, але й формує у студентів усвідомленість того, наскільки і як кожна 3 виучуваних мов може вплинути на процес оволодіння англомовною вимовою. Крім того, робота 3 матеріалом першого та другого типів є, як ми вважаємо, більш доцільною, коли джерелом інтерференції може виступати тільки одна 3 цих мов. Наприклад, для ідентифікації помилок, що полягають у використанні твердого приступу перед голосними на початку слів/складів, ми пропонуємо студентам вправи, засновані на мовленнєвому матеріалі, що продукується носієм німецької мови, а для виявлення помилок у вимові звука $[\mathrm{h}]$ майбутні вчителі аналізують англомовне мовлення людини, що $\epsilon$ носієм української або російської мов.

Підкреслимо, що опрацювання мовленнєвого матеріалу другого типу також готує студентів до навчання учнів англійської мови як IM1, а третього - англійської мови після німецької.

Вправи, що належать до Групи IV, є, як правило, рецептивно-продуктивними, рецептивнорепродуктивними та продуктивними (див. приклад 11).

\section{Приклад 11}

Мета: формування вмінь локалізовувати помилки у вимові звуків у чужому мовленні та читати вголос тексти з метою надання зразка правильної вимови.

Тип вправи: рецептивна (Step 1), репродуктивна (Step 2), некомунікативна, монолінгвальна.

Вид вправи: ідентифікація вимовних помилок у чужому мовленні (Step 1); читання вголос тексту в транскрипції (Step 2).

Завдання: Your friend is planning to take an exam to study abroad but thinks that her pronunciation is not good enough. She wants you to define what mistakes she makes while speaking English.

Step 1. Listen to your friend speaking about her hobby and in the transcription below underline the sounds that are pronounced incorrectly.

laIf Iz ə da:ns\|

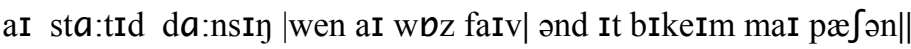

...

Step 2. Read the transcription aloud to give your friend the example of correct pronunciation.

Висновки та перспективи подальших розвідок. На основі сформульованих нами вимог до підсистеми вправ для навчання майбутніх учителів вимови англійської мови після німецької, а також аналізу типів вправ за загальними та спеціальними критеріями ми розробили підсистему вправ, що складається з чотирьох груп відповідно до етапів формування ПФК в англійській мові як IM2. Групи вправ поділено на підгрупи, для кожної з яких запропоновано види вправ.

Перспективою подальших розвідок у цьому напрямку є експериментальна перевірка ефективності розробленої нами підсистеми вправ для формування ПФК в англійській мові після німецької.

\section{СПИСОК ВИКОРИСТАНИХ ДЖЕРЕЛ ТА ЛІТЕРАТУРИ}

1. Долина А. В. Методика вдосконалення фонетичної компетенції у майбутніх учителів англійської мови у самостійній роботі : дис. ...канд. пед. наук : спец. 13.00.02 / Аліна Василівна Долина. - К., 2011. - 274 с. 
2. Ланова О. В. Підготовка майбутніх учителів англійської мови до навчання учнів просодичних засобів : автореф. дис. на здобуття. наук. ступеня канд. пед. наук: спец. 13.00 .02 "Теорія і методика навчання ( германські мови)" / О. В. Ланова. - Одеса, 2008. - 20 с.

3. Перлова В. В. Методика формування у майбутніх учителів англійської мови професійно орієнтованих слуховимовних навичок : дис. ...канд. пед. наук: спец. 13.00.02 / Перлова Вікторія Володимирівна. - Х., 2007. $301 \mathrm{c}$.

4. Чухно О. А. Реалізація принципів формування фонетичної компетентності у майбутніх учителів у процесі навчання англійської мови після німецької / О. А. Чухно // Іноземні мови. - 2016. - №4 (88). - С. $51-57$.

5. Методика навчання іноземних мов i культур : теорія i практика: підручник для студ. класичних, педагогічних і лінгвістичних університетів / [Бігич О. Б., Бориско Н. Ф., Борецька Г. С. та ін.]; за заг. ред. С. Ю. Ніколаєвої. - К. : Ленвіт, 2013. - 590 с.

6. Щукин А. Н. Методика обучения речевому общению на иностранном языке : [учеб. пособ. для препод. и студ. языковых вузов] / А. Н. Щукин. - М. : Издательство Икар, 2011. - 454 с.

7. Чухно О. А. Професійні вміння майбутніх учителів у складі професійної фонетичної компетентності в англійській мові як другій іноземній / О. А. Чухно // Україна і світ : діалог мов та культур : Матеріали міжнародної науково-практичної конференції, 01 - 03 квітня 2015 року. - К. : Вид. центр КНЛУ, 2015. C. $659-662$.

\section{REFERENCES (TRANSLATED \& TRANSLITERATED)}

1. Dolyna A. V. Metodyka vdoskonalennia fonetychnoi kompetentsii u maibutnikh uchyteliv anhliis'koi movy u samostiinii roboti [Methods of Improving Phonetic Competence of Future English Language Teachers in SelfDirected Learning] : dys. ...kand. ped. nauk: spets. 13.00.02 / Alina Vasylivna Dolyna. - K., 2011. - 274 s.

2. Lanova O. V. Pidhotovka maibutnikh uchyteliv anhliis'koi movy do navchannia uchniv prosodychnykh zasobiv [Training Students to Teach English Language Prosody to Schoolchildren]: avtoref. dys. na zdobuttia. nauk. stupenia kand. ped. nauk : spets. 13.00.02 "Teoriia i metodyka navchannia (hermans'ki movy)" / O. V. Lanova. Odesa, 2008. - $20 \mathrm{~s}$.

3. Perlova V. V. Metodyka formuvannia u maibutnikh uchyteliv anhliis'koi movy profesiino oriientovanykh slukhovymovnykh navychok [Methods of Forming Future English Teachers' Professionally-Oriented Pronunciation SubSkills] : dys. ...kand. ped. nauk: spets. 13.00.02 / Perlova Viktoriia Volodymyrivna. - Kh., 2007. - 301 s.

4. Chukhno O. A. Realizatsiia pryntsypiv formuvannia fonetychnoi kompetentnosti u maibutnikh uchyteliv u protsesi navchannia anhliis'koi movy pislia nimets'koi [Realization of Principles of Forming Future Teachers' Phonetic Competence while Teaching English after German] / O. A. Chukhno // Inozemni movy [Foreign Languages]. 2016. - № 4 (88). - S. 51-57.

5. Metodyka navchannia inozemnykh mov i kul'tur : teoriia i praktyka [Methods of Teaching Foreign Languages and Cultures : Theory and Practice] : pidruchnyk dlia stud. klasychnykh, pedahohichnykh i linhvistychnykh universytetiv / [Bihych O. B., Borysko N. F., Borets'ka H. Ye. ta in.]; za zah. red. S. Yu. Nikolaievoi. - K. : Lenvit, 2013. $-590 \mathrm{~s}$.

6. Shhukin A. N. Metodika obucheniia rechevomu obshheniiu na inostrannom jazyke [Methods of Teaching Foreign Language Speaking] : [ucheb. posob. dlia prepod. i stud. jazykovykh vuzov] / A. N. Shhukin. - M. : Izdatel'stvo Ikar, 2011. $-454 \mathrm{~s}$.

7. Chukhno O. A. Profesiini vminnia maibutnikh uchyteliv u skladi profesiinoi fonetychnoi kompetentnosti v anhliis'kii movi yak druhii inozemnii [Future Teachers' Professional Skills in Professional Phonetic Competence in English as the Second Foreign Language] / O. A. Chukhno // Ukraina i svit : dialoh mov ta kul'tur [Ukraine and the World : Dialogue of Languages and Cultures] : Materialy mizhnarodnoi naukovo-praktychnoi konferentsii, $01-03$ kvitnia 2015 roku. - K. : Vyd. tsentr KNLU, 2015. - S. 659-662.

\section{Чухно Е. А. Подсистема упражнений для формирования профессиональной фонетической компетентности в английском языке после немецкого.}

В статье представлена подсистема упражнений для формирования фонетической компетентности

будущих учителей в английском языке после немеикого. Принимая во внимание содержание и пути реализации принщипов обучения будущих учителей английскому языку после немецкого, автор выдвигает требования к упражнениям и выделяет их типы по специальным критериям, обусловленным особенностями обучения будущих учителей произношению второго иностранного языка. $B$ соответствии с этапами формирования профессиональной фонетической компетентности в английском языке после немеикого автор выделяет группы и подгруппь упражнений. Для каждой подгруппы предложены виды упражнений, которые проиллюстрированы примерами.

Ключевые слова: подсистема упражнений, фонетическая компетентность, будущие учителя, второй иностранный язык. 


\section{Chukhno O. A. Subsystem of Exercises for Forming Future Teachers' Phonetic Competence in English after} German.

Effective formation of future teachers' phonetic competence is predetermined by rational organization of their learning. The foundation for this is provided by a subsystem of exercises that serves to define and regulate the teacher's and students' actions in the process of foreign language pronunciation teaching and acquisition correspondingly. So far there have been developed exercises for forming future teachers' phonetic competence in the first foreign language. However, the problem of working out exercises for teaching the pronunciation of English after German still remains unsolved. The study is conducted on the basis of analyzing and generalizing the results of theoretical and practical experience of teaching the pronunciation of English as the first and the second foreign language to future teachers. Having taken into account the contents and the ways of implementing the principles of forming professional phonetic competence in English after German the author determines the requirements for the subsystem of exercises and defines the types of exercises according to specific criteria outlined owing to the peculiarities of teaching the second foreign language pronunciation to future teachers. In accordance with the stages of forming professional phonetic competence in English after German it is proposed to differentiate between four groups of exercises which are further subdivided into several subgroups. For every subgroup the author suggests kinds of exercises and illustrates them with examples. The developed subsystem of exercises may considerably facilitate the process of teaching the pronunciation of English after German to future teachers. Hence, proving its effectiveness experimentally can be considered the next step to be taken in the further elaboration of the research.

Key words: subsystem of exercises, phonetic competence, future teachers, the second foreign language. 